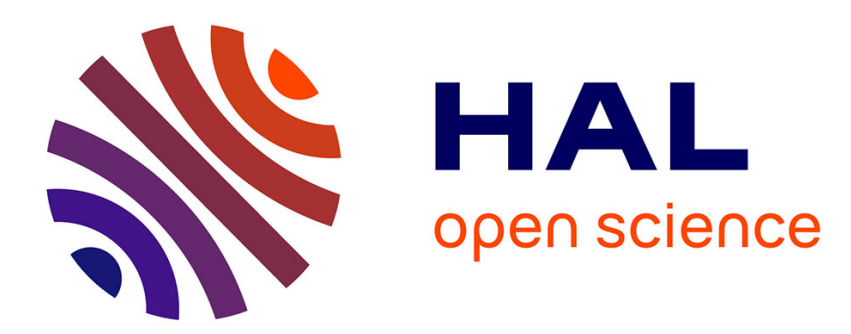

\title{
Abiotic correlates of bee diversity and composition along eastern Neotropics
}

Luiz Faria, Rodrigo Gonçalves

\section{To cite this version:}

Luiz Faria, Rodrigo Gonçalves. Abiotic correlates of bee diversity and composition along eastern Neotropics. Apidologie, 2013, 44 (5), pp.547-562. 10.1007/s13592-013-0205-x . hal-01201325

\section{HAL Id: hal-01201325 \\ https://hal.science/hal-01201325}

Submitted on 17 Sep 2015

HAL is a multi-disciplinary open access archive for the deposit and dissemination of scientific research documents, whether they are published or not. The documents may come from teaching and research institutions in France or abroad, or from public or private research centers.
L'archive ouverte pluridisciplinaire HAL, est destinée au dépôt et à la diffusion de documents scientifiques de niveau recherche, publiés ou non, émanant des établissements d'enseignement et de recherche français ou étrangers, des laboratoires publics ou privés. 


\title{
Abiotic correlates of bee diversity and composition along eastern Neotropics
}

\author{
Luiz Roberto Ribeiro FARIA ${ }^{1}$, Rodrigo Barbosa GonÇALVES ${ }^{2}$ \\ ${ }^{1}$ Departamento de Ciências Agrárias e Biológicas, Centro Universitário do Norte do Espírito Santo, Universidade \\ Federal do Espírito Santo, Rodovia BR-101 Norte, Km 60, Litorâneo, 29932-540, São Mateus, ES, Brazil \\ ${ }^{2}$ Setor Palotina, Universidade Federal do Paraná, Rua Pioneiro, 2153, Jd. Dallas, 85950-000, Palotina, PR, Brazil
}

Received 31 August 2012 - Revised 13 January 2013 - Accepted 19 March 2013

\begin{abstract}
Native bee diversity is poorly documented for many regions of the globe, particularly in the Neotropics. The available structured inventories in this biogeographical region provide reliable data, but they lack a comprehensive interpretation due to the absence of an effort to relate diversity and composition data with environmental variables. We aimed to answer the following questions: (1) Do abiotic factors explain variations in the richness, diversity, and composition of bee assemblages? (2) If so, which abiotic factors explain each of these community descriptors? We used a database comprising 33 systematic surveys of bee assemblages along eastern Neotropics. We found significant effect of abiotic variables on biotic diversity parameters and assemblage composition. Temperature annual range was the main abiotic predictor affecting bee richness and diversity, while composition was explained by annual mean temperature, temperature seasonality, temperature annual range, and by annual precipitation.
\end{abstract}

Apidae / Apoidea / bee fauna / diversity / pollinator

\section{INTRODUCTION}

It has been recognized that the main importance of bees in the ecosystems is their pollination services for natural vegetation (Michener 2007). Many cultivated plants need bees as pollinators, and natural areas can support a number of potential pollinators for these crops and orchards (e.g., Steffan-Dewenter 2003). Due to anthropic pressures, especially extensive habitat loss (Winfree et al. 2009), these insects are considered under diversity decline (e.g., Biesmeijer et al. 2006), with some local extinction reports (e.g., Kosior et al. 2007; Martins \& Melo 2010), and with commitment to ecosystem process (Schleuning et al.

Corresponding author: L.R.R. Faria, nunofariajr@gmail.com

Manuscript Editor: Marina Meixner
2011). The impacts on bees are worldwide and the concern is surely applied to megadiverse tropical areas which fauna are far from being properly described. As an example, in Brazil, there are about 1,700 known bee species (Melo 2007), but the richness is estimated to be 3,000 species, more than $10 \%$ of the entire global bee diversity (Silveira et al. 2002a). This noticeable richness can be related to the continental size of this country combined to the great diversity of landscapes.

Many efforts to document the Brazilian bee fauna are concentrated in standardized inventories, which summed more than 80 studies so far (up-todate number follows Pinheiro-Machado (2002); see also Biesmeijer et al. 2005). These inventories are based on net sampling flower visitors in a previously defined area of usually few hectares for about a 1-year period (Sakagami et al. 1967). This active sampling can be disadvantageous due to the 
difficulty to replicate the sampling effort among different studies, but it is for long considered the best way to sample a diversity of bees groups in distinct vegetation kinds (Laroca and Orth 2002). The available studies usually report bee assemblages as species abundance lists, often with additional data of seasonality (e.g., Aguiar and Martins 2003; Aguiar and Zanella 2005; Madeirada-Silva and Martins 2003) and flower visit records (e.g., Faria-Mucci et al. 2003; Gonçalves and Melo 2005).

These bee inventories, as for active sampling of other insects, have some important challenges that can prevent the representation of the assemblages and the comparison among them. The first challenge is to encompass the great heterogeneity of habitats in order to produce an accurate checklist that can be considered representative of a certain area (Gonçalves et al. 2009). A second is the difficulty to standardize the effort of sampling, due to bias on sampling intervals, number of collectors, and seasonality (Cure et al. 1991. A third is the complication to handle with the taxonomical impediment (Silveira et al. 2002b), the lack of revised scientific names that constraint the identification at species level, leaving many unidentified specimens determined as morphospecies.

Another important issue is how to contextualize the results of the inventories with biotic and abiotic variables (Grundel et al. 2010). For this contextualization, it is necessary to have a background of how richness, diversity, abundance, and composition of bees from different assemblages correlate with the environment. Few attempts were made to produce these comparative studies and/or meta-analysis on bee sinecology, and these are restricted to exploitation of particular ecosystems, bee groups, and analytical approaches (Silveira and Campos 1995; Zanella 2000; Biesmeijer and Slaa 2006; Gonçalves et al. 2009; Sydney et al. 2010). Examples of interesting results of these attempts are: the indication that different open vegetation ecosystems have particular genus composition (Silveira and Campos 1995; Gonçalves et al. 2009); the relationship between stingless bee richness and latitude (Biesmeijer and Slaa 2006); and the influence of latitudinal, longitudinal (Sydney et al. 2010), precipitation (Abrahamczyk et al. 2011; Sydney et al. 2010), and temperature seasonality (Abrahamczyk et al. 2011) gradients on orchid bee communities.

Despite the aforementioned attempts, there is no single study to compare the structure of bee communities relating their biotic (i.e., diversity related) parameters to environmental variables. In this context, the goal of the present work is to explore the role of abiotic factors on bee assemblages in eastern Neotropics. The specific addressed questions are: (1) Do abiotic factors explain variations in the richness, diversity, and composition of bee assemblages? (2) If so, which abiotic factors explain each of these community descriptors?

\section{MATERIAL AND METHODS}

\subsection{Database}

We used a database comprising 33 systematic surveys of bee assemblages concentrated on eastern Neotropics, due to the inexistence or scarcity of systematic surveys on western, northern, and southern portion of the region. The inclusion of surveys relied upon the following criteria: (1) studies comprising at least 9 months including, necessarily, the hot season; (2) active netting as sampling method; (3) presence of species lists with respective abundances; and (4) studies carried out in restricted areas (few hectares), with geographic coordinates available. Presence and abundance of the exotic Apis mellifera Linnaeus, 1758, the Africanized honey bee, was not considered for the construction of the database. A list of the selected studies appears on Table I, and the geographical range of them can be evaluated in Figure 1.

Abiotic data were obtained from the WorldClim database, with spatial resolution of $2.5 \mathrm{~min}$ and comprising the 1950-2000 period (Hijmans et al. 2005). We firstly selected the annual mean temperature (BIO1) and annual precipitation (BIO12), but consider the inclusion of temperature (BIO4) and precipitation seasonality (BIO15) and also the temperature annual range (BIO7), assuming that the seasonality is an important issue on bee communities. 
Table I. Surveys along eastern Neotropical region considered in this study.

\begin{tabular}{|c|c|c|c|c|c|c|c|c|}
\hline Code & Location & Latitude & Longitude & Vegetation & $\mathrm{SR}^{*}$ & $N$ & SR & Reference \\
\hline MAPA & $\begin{array}{l}\text { Panaquatira, } \\
\text { MA }\end{array}$ & 2.47 & -44.05 & $\begin{array}{r}\text { Coastal } \\
\text { Dunes }\end{array}$ & 30 & 2,641 & 21 & $\begin{array}{l}\text { Oliveira et al. } \\
(2010)\end{array}$ \\
\hline MAVI & $\begin{array}{l}\text { Vitória do } \\
\text { Mearim, MA }\end{array}$ & -3.48 & -44.5 & Capoeira & 36 & 866 & 32 & $\begin{array}{l}\text { Albuquerque et al. } \\
(2001)\end{array}$ \\
\hline TOES & $\begin{array}{l}\text { Esperantina, } \\
\text { TO }\end{array}$ & -5.33 & -48.58 & $\begin{array}{l}\text { Cerrado/ } \\
\text { DOF }\end{array}$ & 82 & 1,672 & 57 & Santos et al. (2004) \\
\hline RNSN & $\begin{array}{l}\text { Serra Negra } \\
\text { do Norte, RN }\end{array}$ & -6.57 & -37.25 & Caatinga & 82 & 1,155 & 61 & Zanella (2003) \\
\hline PBMA & $\begin{array}{l}\text { Mamanguape, } \\
\text { PB }\end{array}$ & -6.67 & -35.2 & Caatinga & 113 & 2,361 & 74 & $\begin{array}{l}\text { Aguiar and Martins } \\
\text { (2003) }\end{array}$ \\
\hline PBCA & Cabedelo, PB & -7.05 & -35.85 & Caatinga & 39 & 974 & 34 & $\begin{array}{l}\text { Madeira-da-Silva } \\
\text { and Martins } \\
(2003)\end{array}$ \\
\hline PBSJ & $\begin{array}{c}\text { São João do } \\
\text { Cariri, PB }\end{array}$ & -7.42 & -36.5 & Caatinga & 40 & 839 & 31 & $\begin{array}{l}\text { Aguiar and Martins } \\
\text { (1997) }\end{array}$ \\
\hline PECG & $\begin{array}{l}\text { Chã-Grande, } \\
\text { PE }\end{array}$ & -8.19 & -35.47 & Caatinga & 79 & 889 & 65 & $\begin{array}{l}\text { Millet-Pinheiro and } \\
\text { Schlindwein } \\
(2008)\end{array}$ \\
\hline $\mathrm{BACN}$ & Casa Nova, BA & -9.43 & -41.83 & Caatinga & 42 & 507 & 34 & Martins (1994) \\
\hline BALE & Lençois, BA & -12.57 & -41.38 & Caatinga & 151 & 1,490 & 90 & Martins (1990) \\
\hline BAIT & Itatim, BA & -12.70 & -39.77 & Caatinga & 59 & 557 & 55 & $\begin{array}{l}\text { Aguiar and Zanella } \\
\text { (2005) }\end{array}$ \\
\hline DFBR & Brasília, DF & -15.87 & -47.85 & Cerrado & 215 & 2,438 & 115 & Boaventura (1998) \\
\hline GOIP & Iporá, GO & -16.45 & -51.13 & Cerrado & 61 & 818 & 46 & $\begin{array}{l}\text { Santiago et al. } \\
(2009)\end{array}$ \\
\hline MGLN & $\begin{array}{l}\text { Lavras Novas, } \\
\text { MG }\end{array}$ & -19.30 & -43.58 & Cerrado & 72 & 576 & 65 & $\begin{array}{l}\text { Faria-Mucci et al. } \\
(2003)\end{array}$ \\
\hline MGSR & $\begin{array}{l}\text { Santana do } \\
\text { Riacho, MG }\end{array}$ & -19.30 & -43.58 & Cerrado & 107 & 632 & 94 & $\begin{array}{l}\text { Faria and Camargo } \\
\text { (1996) }\end{array}$ \\
\hline MGPA & Paraopeba, MG & -19.33 & -44.33 & Cerrado & 172 & 1,135 & 123 & $\begin{array}{l}\text { Silveira and } \\
\text { Campos (1995) }\end{array}$ \\
\hline SPCA & Cajuru, SP & -21.33 & -47.27 & Cerrado & 195 & 3,509 & 89 & Pedro (1992) \\
\hline SPLA & $\begin{array}{l}\text { Luis Antonio, } \\
\text { SP }\end{array}$ & -21.55 & -47.85 & Cerrado & 138 & 2,687 & 74 & Mateus (1998) \\
\hline SPCO & $\begin{array}{l}\text { Corumbataí, } \\
\text { SP }\end{array}$ & -22.25 & -47.0 & Cerrado & 123 & 708 & 100 & $\begin{array}{l}\text { Silveira and } \\
\text { Campos (1995) }\end{array}$ \\
\hline SPSP & São Paulo, SP & -23.37 & -46.43 & DOF & 168 & 6,028 & 61 & Ramalho (1995) \\
\hline SPSA & $\begin{array}{l}\text { Salesópolis, } \\
\text { SP }\end{array}$ & -23.63 & -45.87 & DOF & 258 & 6,748 & 113 & Wilms (1995) \\
\hline PRJA & $\begin{array}{l}\text { Jaguariaíva, } \\
\text { PR }\end{array}$ & -24.17 & -49.65 & Cerrado & 167 & 1,491 & 81 & Almeida (2003) \\
\hline PRTP & $\begin{array}{l}\text { Tunas do } \\
\text { Paraná, PR }\end{array}$ & -25.03 & -49.08 & SSF & 135 & 733 & 110 & Weiss (2008) \\
\hline PRPG & $\begin{array}{l}\text { Ponta Grossa, } \\
\text { PR }\end{array}$ & -25.23 & -49.99 & OE & 181 & 1,122 & 122 & $\begin{array}{c}\text { Gonçalves and } \\
\text { Melo (2005) }\end{array}$ \\
\hline PRAN & Antonina, PR & -25.32 & -48.66 & DOF & 118 & 844 & 91 & Maia (2008) \\
\hline PRGU & $\begin{array}{l}\text { Guarapuava, } \\
\text { PR }\end{array}$ & -25.39 & -51.46 & $\mathrm{OE}$ & 148 & 1,733 & 88 & $\begin{array}{l}\text { Bortoli and Laroca } \\
\text { (1997) }\end{array}$ \\
\hline
\end{tabular}


Table I (continued)

\begin{tabular}{lllllllll}
\hline Code & Location & Latitude & Longitude & Vegetation & SR* & $N$ & SR & Reference \\
\hline PRCU & Curitiba, PR & -25.48 & -49.24 & OE & 120 & 1,439 & 72 & Cure et al. (1991) \\
PRMO & Morretes, PR & -25.48 & -48.82 & DOF & 111 & 1,194 & 84 & Barbola (2000) \\
PRLA & Lapa, PR & -25.73 & -49.78 & OE & 159 & 2,361 & 88 & $\begin{array}{c}\text { Barbola and Laroca } \\
(1993)\end{array}$ \\
SCSB & $\begin{array}{c}\text { São Bento do } \\
\text { Sul, SC }\end{array}$ & -26.05 & -49.05 & DOF & 71 & 682 & 58 & $\begin{array}{c}\text { Mouga and Krug } \\
\text { (2010) }\end{array}$ \\
PRPB & $\begin{array}{c}\text { Pato Branco, } \\
\text { PR }\end{array}$ & -26.23 & -52.68 & OE & 146 & 1,069 & 94 & $\begin{array}{c}\text { Jamhour and Laroca } \\
\text { (2004) }\end{array}$ \\
SCPU & $\begin{array}{c}\text { Porto União, } \\
\text { SC }\end{array}$ & -26.32 & -50.92 & MOF & 129 & 498 & 124 & $\begin{array}{c}\text { Krug and Alves- } \\
\text { dos-Santos (2008) }\end{array}$ \\
RSVI & Viamão, RS & -30.08 & -51.03 & SE & 140 & 1,597 & 92 & \begin{tabular}{c} 
Hoffmann (1990) \\
\hline
\end{tabular}
\end{tabular}

$S R^{*}$ original species richness, $N$ number of specimens, $S R$ rarefied species richness (cutoff, 450 individuals, see Section 2). Vegetation: Capoeira secondary vegetation composed of grasslands and scattered shrubs, DOF dense ombrophylous forest, $S S F$ semidecidual seasonal forest, $O E$ ombrophylous estepe, $S E$ seasonal estepe. Brazilian political divisions: $B A$ Bahia, $D F$ Distrito Federal, $G O$ Goiás, $M A$ Maranhão, $M G$ Minas Gerais, $P B$ Paraíba, $P E$ Pernambuco, $P R$ Paraná, $R N$ Rio Grande do Norte, $R S$ Rio Grande do Sul, $S C$ Santa Catarina, SP São Paulo, TO Tocantins

Regarding altitude, the original values presented by the authors in the original papers were always preferred, but in the case this information was missing, the value was also assessed in WorldClim database.

\subsection{Analysis}

In order to compare the richness in the different studies, we used the rarefaction method based on the number of individuals. This technique is used to approach the richness expected in a subsample of specimens selected at random from a larger sample (Sanders 1968; Hurlbert 1971; Simberloff 1972; Koellner et al. 2004). Instead of using a cutoff score equivalent to the survey with the lowest abundance (498 individuals in Krug and Alves-dos-Santos 2008), we used a standardized subset of 450 individuals to allow even sub-sampling with the lowest number of bees collected in the dataset. Besides species richness $(\mathrm{SR})$, Shannon diversity index $\left(\mathrm{H}^{\prime}\right)$, probability of an interspecific encounter (PIE; Hurlbert 1971) was utilized as a evenness measure, and the Dominance index (D) were calculated based on the rarefied dataset; all calculations were carried out with EcoSim (Gotelli and Entsminger 2004). Verification of the hypothesis of normality was made by using the Jarque-Bera test (Jarque and Bera 1980; see Thadewald and Büning (2007)). As normality was not achieved for PIE and D, in these cases, data were transformed according to the logit procedure as recommended by Warton and Hui (2011).

Regarding composition of bee assemblages, a non-metric multidimensional scaling ordination analysis (NMDS) was performed based on Jaccard's similarity index, a standard index for binary data. This analysis, regarded by ecologists as one of the most robust ordination methods (e.g., Minchin 1987), is a nonlinear data-dependent technique applicable to the analysis of wide environmental gradients (Ludwig and Reynolds 1988). The NMDS stress was calculated to approach the quality of this analysis. Stress values lower than 0.2 are regarded to represent a good adjustment of the ordination (Clarke and Warwick 2001). For this analysis, a presence/ absence matrix of bee genera was constructed based on the data from the 33 selected surveys. The comparison between assemblages from different locations is only possible using genera as units of comparison due to the high number of unidentified species (Gonçalves et al. 2009). The values of the first two axes of NMDS were then selected to be analyzed as the variables regarding composition of the assemblages. 


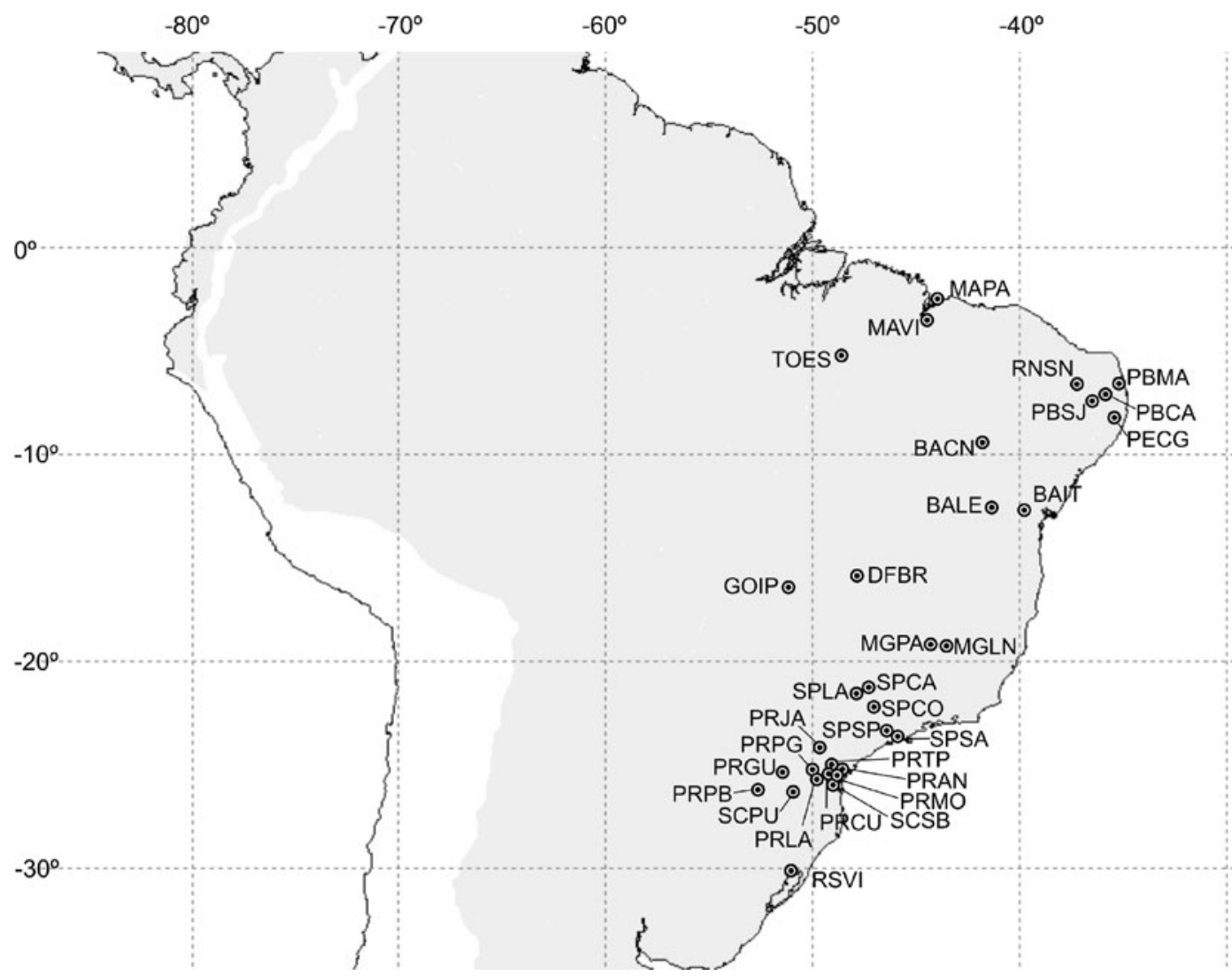

Figure 1. Bee assemblages along Neotropics included in the analysis. Neotropical region (sensu Morrone 2006) is depicted in gray. Abbreviations according to Table I.

Initially, Pearson correlations were utilized to explore the relationships between the descriptors of the selected assemblages (dependent variables at 450 individuals: SR, PIE, $\mathrm{H}^{\prime}, \mathrm{D}$, and NMDS axes) and the environmental predictors. We then used linear models (ordinary least squares regressions, OLS) to test the effect of the predictors on the dependent variables. A model selection approach, using the Akaike Information Criterion (AIC) (Burnham and Anderson 2002), was utilized to recognize the best among all possible models, i.e., all the different combinations of predictors for each of the descriptors of assemblages. In order to avoid the collinearity problem, the variance inflation factors (VIFs) and the condition number $(\mathrm{CN})$ values for each model were analyzed (see, e.g., O'Brien (2007) and Lazaridis (2007)). Maximum VIF values lower than 10 (Mason et al. 1989; Neter et al. 1989) and $\mathrm{CN}$ values lower than 5 (Lazaridis 2007) were considered as indicating that collinearity was not a major problem for a given model. When the best model was composed by two or more variables, a partial regression analysis was performed to evaluate the proportion of variance explained by each variable.

Since observed relationships in ecology tend to be spatially variable ("nonstationarity"), even if the underlying ecological processes are more general, the realized patterns will vary with local conditions (e.g., Jetz et al. 2005; Cassemiro et al. 2007). As neighboring residuals tend to be more similar than distant ones, the significance and values of model parameters may be affected (see Diniz-Filho et al. (2003)). We utilized geographical weighted regression (GWR) procedures to deal with spatial autocorrelation. These analyses were performed with a bisquare spatial weighting function and with bandwidth optimized to minimize AIC values.

Statistical analyses were performed in Past (Hammer et al. 2001) and Spatial Analysis in Macroecology (SAM; Rangel et al. 2010) software packages. 


\section{RESULTS}

In general, significant correlations were found among assemblage parameters and abiotic predictors (Figures 2, 3, 4, and 5; Table II). Species richness, more specifically, appeared positively correlated with altitude, temperature seasonality (BIO4), temperature annual range (BIO7), and annual precipitation (BIO12), and negatively correlated with annual mean temperature (BIO1) and precipitation seasonality (BIO15). The same pattern of correlation was found for the Shannon diversity index. The taxonomic composition was also related to the abiotic predictors, NMDS1 with all the predictors, and NMDS2 only with annual precipitation.

Regarding the ordination analysis (NMDS; $S=$ $0.175)$, it was not possible to recognize distinct groupings of assemblages, which could be related to the vegetation cover. Nonetheless, the analysis suggests a gradient where genera composition from tropical areas (mainly negative values on NMDS1) are being replaced towards to colder regions (mainly positive values on NMDS1) along the first ordination axis (Figure 6). This interpretation is supported by the OLS results for the first axis of NMDS (see below).

In relation to regression analysis (Table III), the best model explaining community structure (SR, H', PIE, and D) included only the temperature annual range (BIO7) $\left(\mathrm{SR}: r^{2}=\right.$ $0.456, P<0.001 ; \mathrm{H}^{\prime}: r^{2}=0.346, P<0.001$; PIE: $\left.r^{2}=0.278, P=0.002 ; \mathrm{D}: r^{2}=0.205, P=0.008\right)$. With respect to variables related to taxonomic composition (NMDS axes), the selected models were more complex. The best model for the first axis (NMDS1) included annual mean temperature (BIO1) and temperature seasonality (BIO4)
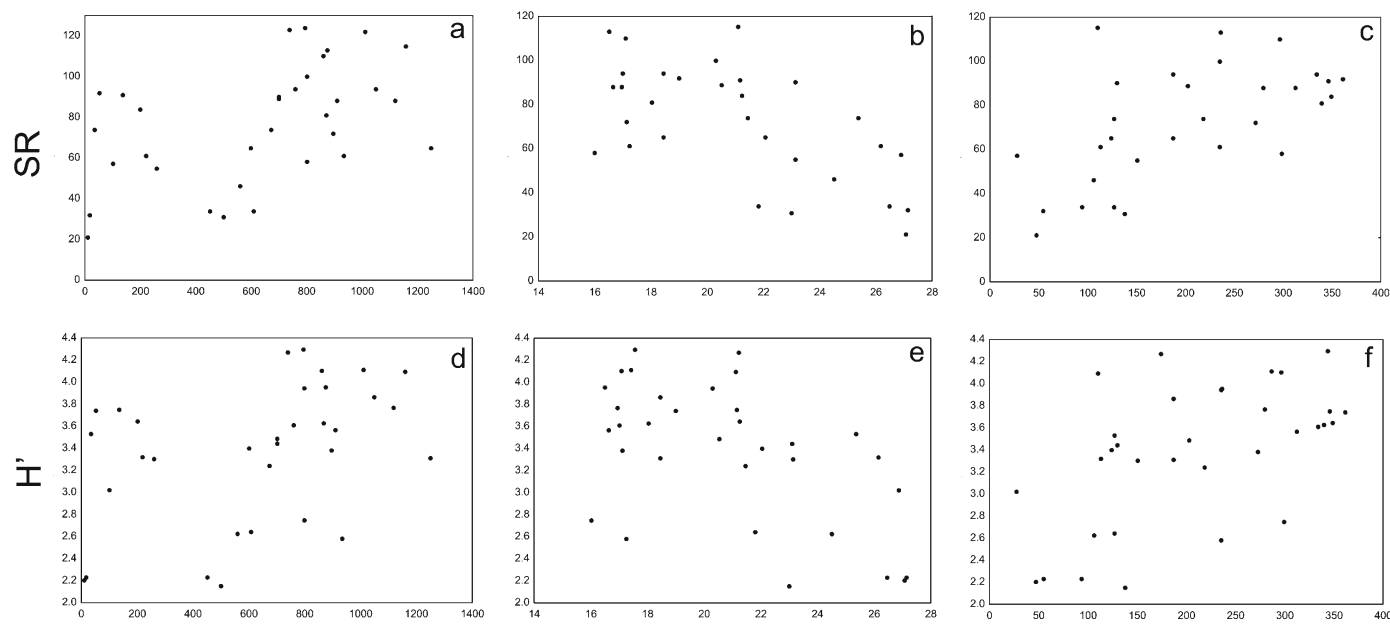

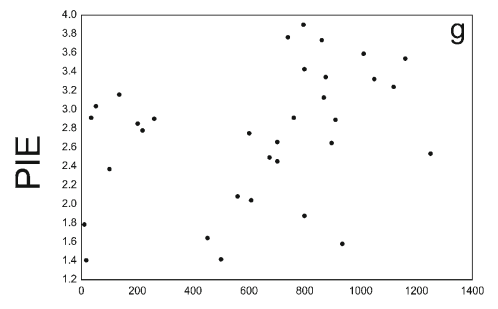

Altitude

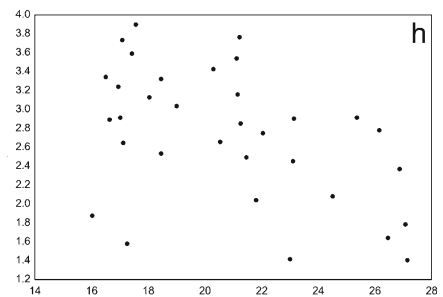

$\mathrm{BIO} 1$

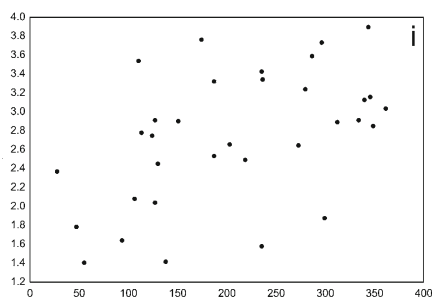

$\mathrm{BIO} 4$

Figure 2. Scatter plots correlating assemblages' parameters and abiotic variables. a SR $\times$ altitude, $\mathbf{b} \mathrm{SR} \times \mathrm{BIO} 1$, c $\mathrm{SR} \times \mathrm{BIO} 4$, d $\mathrm{H}^{\prime} \times$ altitude, e $\mathrm{H}^{\prime} \times \mathrm{BIO} 1$, f $\mathrm{H}^{\prime} \times \mathrm{BIO} 4$, g $\mathrm{PIE} \times$ altitude, h $\mathrm{PIE} \times \mathrm{BIO} 1$, i $\mathrm{PIE} \times \mathrm{BIO} 4$. For abbreviations, see Section 2. 

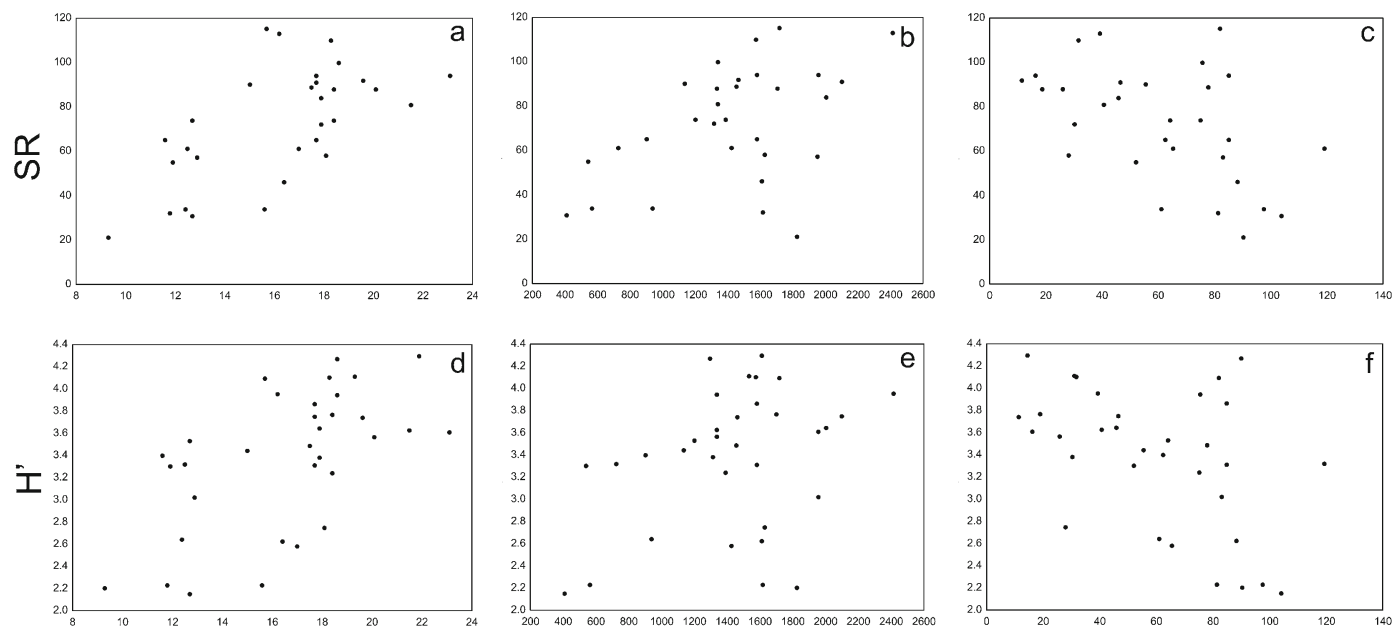

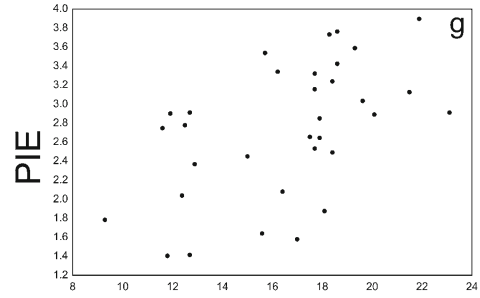

$\mathrm{BIO} 7$

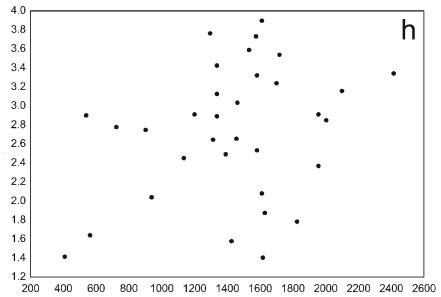

$\mathrm{BIO} 12$

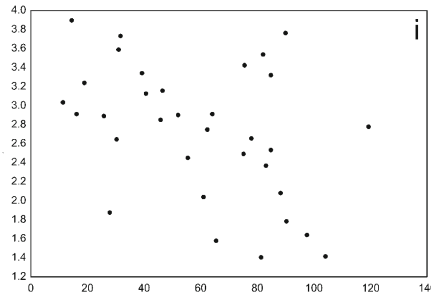

BIO 15

Figure 3. Scatter plots correlating assemblages' parameters and abiotic variables. a SR $\times \mathrm{BIO} 7, \mathbf{b} \mathrm{SR} \times \mathrm{BIO} 12$, c $\mathrm{SR} \times \mathrm{BIO} 15, \mathbf{d} \mathrm{H}^{\prime} \times \mathrm{BIO} 7$, e $\mathrm{H}^{\prime} \times \mathrm{BIO} 12, \mathbf{f} \mathrm{H}^{\prime} \times \mathrm{BIO} 15$, g $\mathrm{PIE} \times \mathrm{BIO} 7$, h $\mathrm{PIE} \times \mathrm{BIO} 12$, i $\mathrm{PIE} \times \mathrm{BIO} 15$. For abbreviations, see Section 2.

$\left(r^{2}=0.757, P<0.001\right)$, but these effects on the first axis were opposite (BIO1: $t=-3.170, P=$ 0.004; BIO4: $t=2.736, P=0.011)$. Partial regression analysis revealed that $\mathrm{BIO} 1$ and $\mathrm{BIO} 4$ shared most of the variance explained by them (0.615; against 0.081 explained by $\mathrm{BIO} 1$ and 0.061 explained by BIO4 only). This way, the survey distribution on the first axis of NMDS respected a decrease on annual mean temperature, while the temperature seasonality increased. Regarding the second axis of variation (NMDS2), the best model included temperature annual range (BIO7) and annual precipitation (BIO12; $\left.r^{2}=0.485, P<0.001\right)$. When considered by themselves, only BIO12 explained the variance on NMDS2 $(t=5.297, P<0.001)$. The partial regression results attested to the major importance of precipitation, since the variance explained only by BIO12 (0.482) was much higher than explained by BIO7 itself (0.041; shared explained variance, -0.038 ).

The GWR analysis, taking spatial structure into account, showed very similar patterns to those found in OLS analysis. The exception was $\mathrm{D}$, since we found no significant values for GWR analysis despite the results found when performing the standard regression (Table IV).

\section{DISCUSSION/CONCLUSION}

In relation to the first specific objective of this study, abiotic variables were correlated with diversity and composition of bee assemblages along eastern Neotropics. It is important to note that in many cases we found, despite their statistical significance, low values of $r$ and $r^{2}$ (regarding, respectively, correlation, and regression analyses). This shows that, although these 

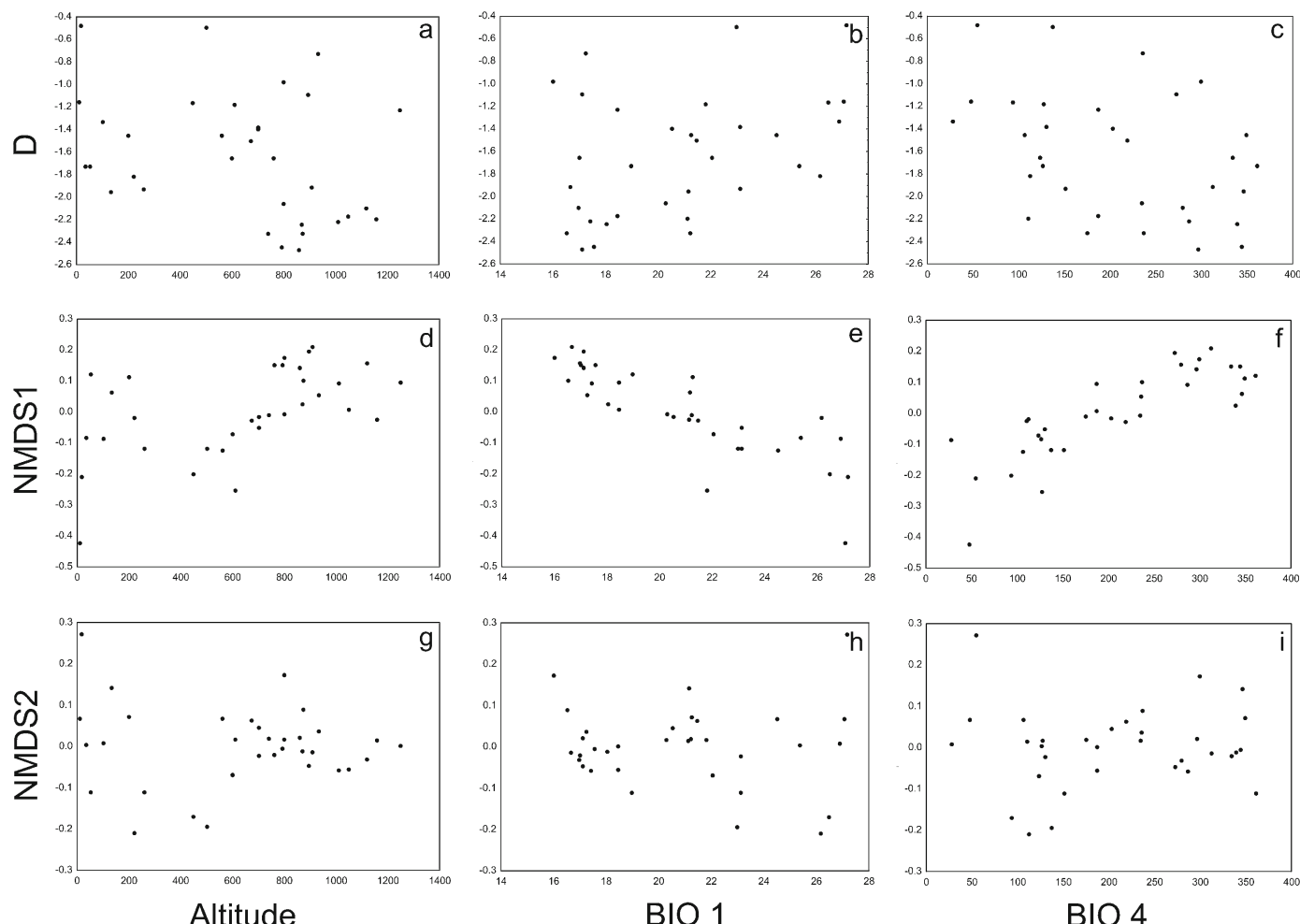

$\mathrm{BIO} 4$

Figure 4. Scatter plots correlating assemblages' parameters and abiotic variables. a $\mathrm{D} \times$ altitude, $\mathbf{b} \mathrm{D} \times \mathrm{BIO} 1, \mathbf{c}$ $\mathrm{D} \times \mathrm{BIO} 4$, d NMDS1 $\times$ altitude, e NMDS1 $\times \mathrm{BIO} 1$, f NMDS1×BIO 4, g NMDS2 $\times$ altitude, h NMDS2 $\times$ BIO 1 , i NMDS2 $\times$ BIO 4. For abbreviations, see Section 2 .

climatic variables are quite relevant to understand how bee richness, diversity and composition vary along Neotropics, these parameters are too complex to be explained only by the abiotic predictors considered in the regression models analyzed in this paper (see discussion above).

Regarding the regression analyses, diversity and composition were explained by different set of abiotic variables. Temperature annual range, the difference between the higher and lesser temperatures, was the most important factor describing bee diversity, as we observed an increase in species richness, $\mathrm{H}$, and PIE, besides a decrease in $\mathrm{D}$, at places with higher temperature annual range.

On the other side, the generic composition of bee assemblages varied in response to annual mean temperature and temperature seasonality (NMDS1), and to temperature annual range and annual precipitation (NMDS2). The bee composition analysis was based on the presence/absence matrix of bee genera, which adds an historic perspective, in the sense of a deeper relation of these supra-specific taxa with the localities. The NMDS1 (Figure 6) suggests a spatial gradient pattern, with a subtle separation of -21 and lower latitudes areas (Dry Forests, Cerrado and Caatinga) and -22 and higher latitudes areas (Atlantic Forest and grasslands). This separation possibly reflects a bee composition response to annual mean temperature and temperature seasonality, the abiotic correlates of NMDS axis 1. A gradient between Cerrado and the southern grasslands areas was discussed by Gonçalves et al. (2009), but the hereby inclusion of other vegetational areas did not quantitatively enhance the understanding of how bee composition varies among different biomes. The NMDS2 showed a different gradient, 

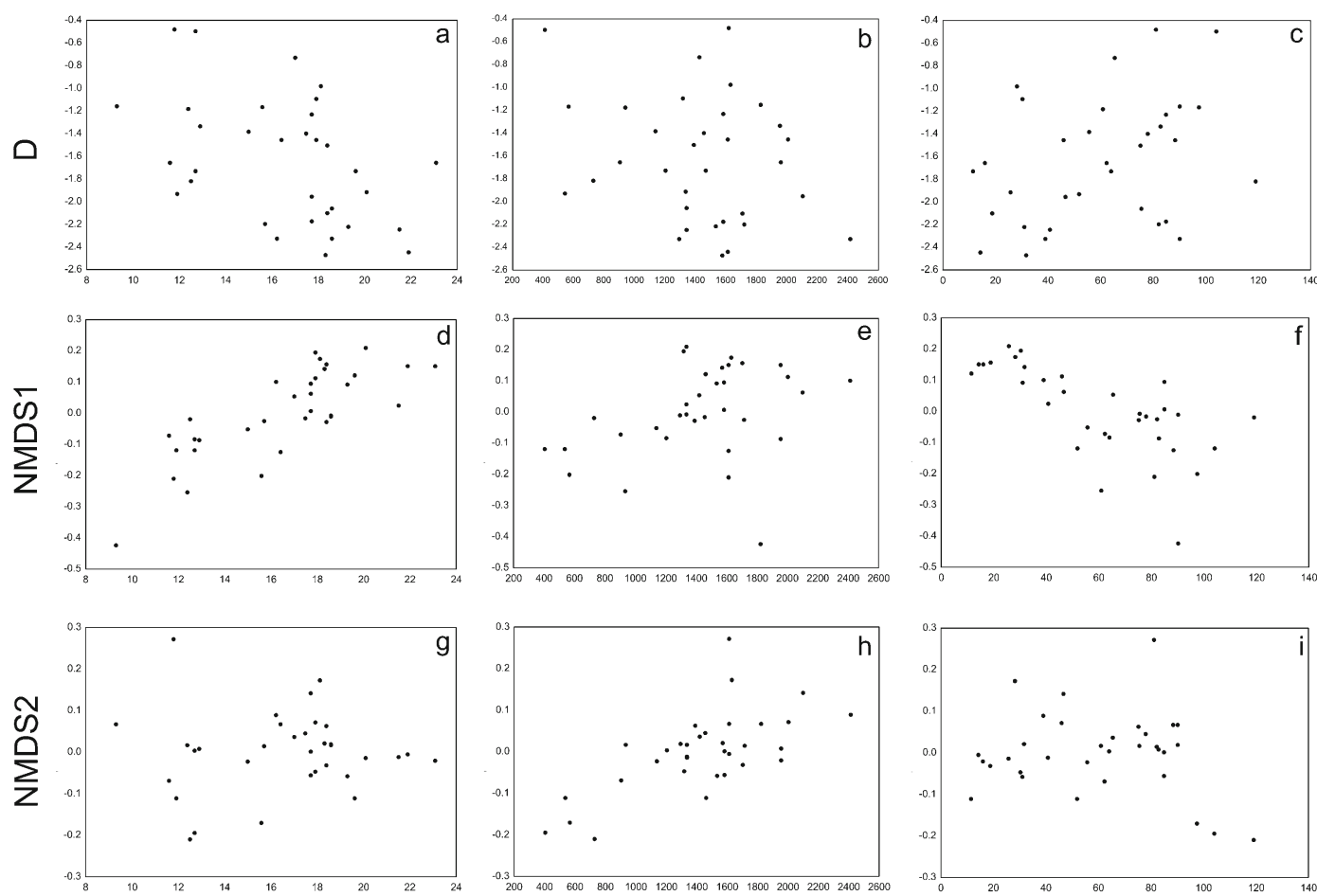

$\mathrm{BIO} 7$

$\mathrm{BIO} 12$

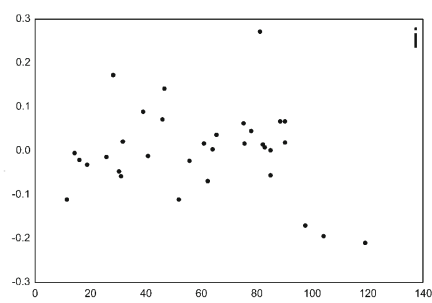

$\mathrm{BIO} 15$

Figure 5. Scatter plots correlating assemblages' parameters and abiotic variables. a $\mathrm{D} \times \mathrm{BIO} 7, \mathbf{b} \mathrm{D} \times \mathrm{BIO} 12$, c: $\mathrm{D} \times \mathrm{BIO} 15$, d NMDS1 $\times$ BIO 7, e NMDS $1 \times \mathrm{BIO} 12, \mathbf{f}$ NMDS $1 \times \mathrm{BIO} 15, \mathbf{g}$ NMDS2 $\times \mathrm{BIO} 7, \mathbf{h}$ NMDS2 $\times \mathrm{BIO}$ 12, i NMDS2 $\times$ BIO 15. For abbreviations, see Section 2 .

explained mainly by annual precipitation, a vari- a biome known for water stress and historic lower able for long recognized as related to diversity precipitation values (Zanella 2000; 2003), have patterns (Gaston 2000). The localities of Caatinga, shown higher negative values on this axis, and this

Table II. Pearson correlation coefficients of assemblages' parameters and abiotic variables.

\begin{tabular}{lcllccc}
\hline Parameter & Altitude & BIO 1 & BIO 4 & BIO 7 & BIO 12 & BIO 15 \\
\hline SR & $0.481^{*}$ & $-0.611^{* *}$ & $0.585^{* *}$ & $0.675^{* *}$ & $0.409^{* * *}$ & $-0.478^{*}$ \\
$\mathrm{H}^{\prime}$ & $0.403^{* * *}$ & $-0.546^{*}$ & $0.556^{* *}$ & $0.587^{* *}$ & $0.344^{* * *}$ & $-0.465^{*}$ \\
PIE & $0.358^{* * *}$ & $-0.477^{*}$ & $0.499^{*}$ & $0.528^{*}$ & 0.303 & $-0.422^{*}$ \\
$\mathrm{D}$ & -0.322 & $0.388^{* * *}$ & $-0.406^{* * *}$ & $-0.453^{*}$ & -0.251 & $0.352^{* * *}$ \\
NMDS1 & $0.518^{*}$ & $-0.834^{* *}$ & $0.822^{* *}$ & $0.786^{* *}$ & $0.347 * * *$ & $-0.681^{* *}$ \\
NMDS2 & -0.060 & -0.065 & 0.071 & 0.054 & $0.666^{* *}$ & -0.154 \\
\hline
\end{tabular}

Cutoff (in all cases): 450 individuals, see Section 2

$S R$ rarefied species richness, $H^{\prime}$ rarefied Shannon index, $P I E$ rarefied proportion of interespecific encounter, $D$ rarefied dominance index, NMDS1 and NMDS2 values for the first and second axis of ordination in the NMDS analysis, BIO1 annual mean temperature, $\mathrm{BIO} 4$ temperature seasonality, $\mathrm{BIO}$ temperature annual range, $\mathrm{BIO} 12$ annual precipitation, $\mathrm{BIO} 15$ precipitation seasonality

$* P<0.01, * * P<0.001, * * * P<0.05$ 


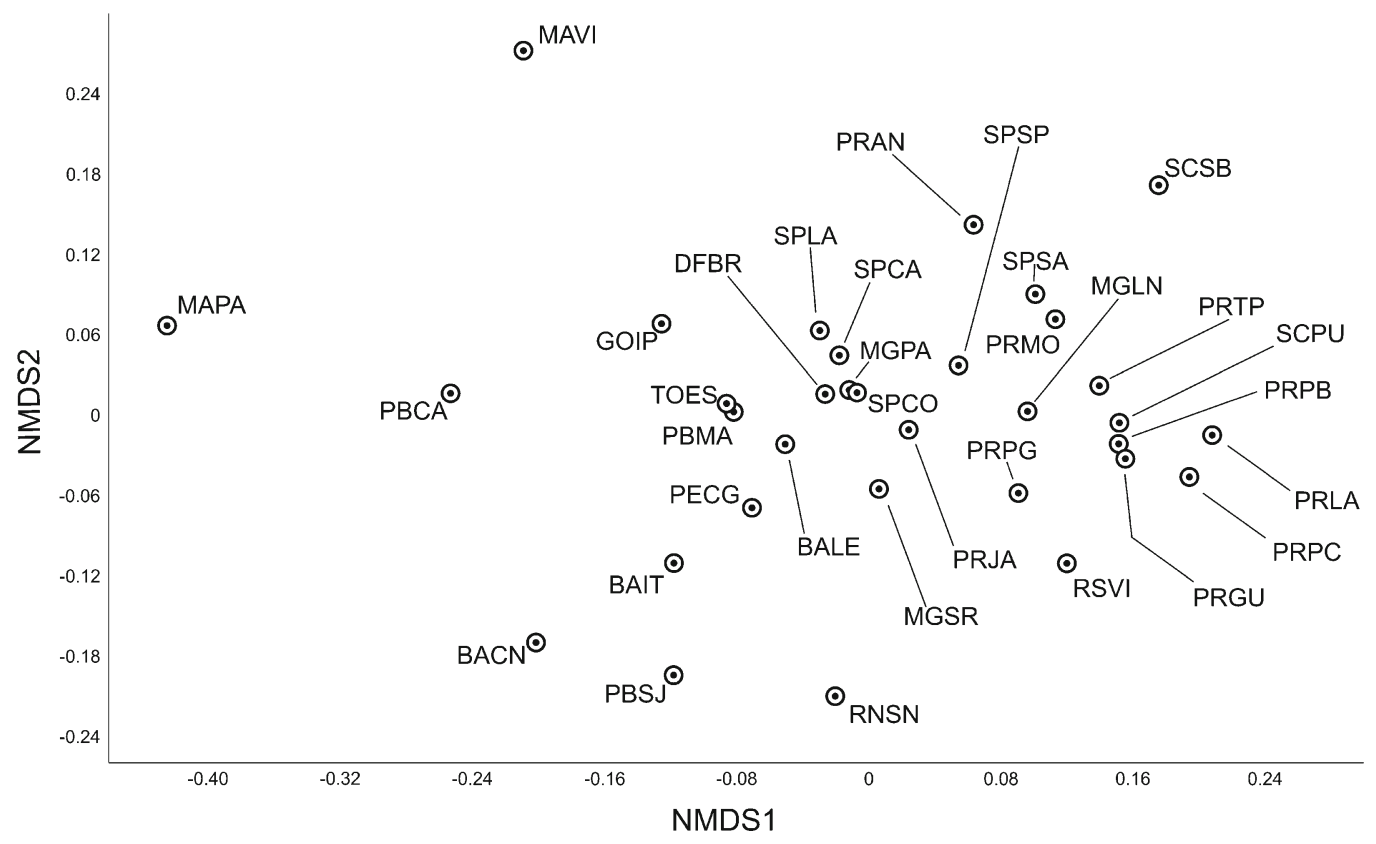

Figure 6. NMDS ordination plot. $S=0.175$. Abbreviations according to Table I.

dry condition found in Caatinga is probably also reflected in bee diversity. The precipitation in this case has an indirect effect on the bee diversity: higher precipitation affects positively the flower resources, while bees themselves response negatively to rainfall (Gonzalez et al. 2009).

It is important to note that the present objective was not to test the response of Neotropical bees (regarding diversity and composition) to the latitudinal gradient. However, as the abiotic variables tested here are correlated with latitude, its influence permeates our discussion. It has been generalized that for most of the organisms there is a decline of biodiversity with the latitude (e.g., Hildebrand 2004), but the opposite tendency is frequently reported (Willig et al. 2003) and, possibly, this is the case of bees (see discussion below).

When we consider the influence of abiotic correlates on bee diversity, two main reasons are suggested for that: (1) a deeper, historic association, defined by composite causes; (2) the importance of a broad temperature range for species coexistence mediated by temporal species turnover.
First of all, the response to the abiotic gradient reflects the historic association of bees and areas with lower latitudes, and consequently higher temperature range and other related abiotic correlates. Michener`s classic "Biogeography of the Bees" (1979) generalized that bee diversity and abundance was greater in warm temperate areas than on tropics. For the Neotropical region, Michener (1979) points that areas from southern Brazil and Argentina have a more speciose bee fauna comparatively to northern areas. This observation is also perceived for composition; it is quite difficult to separate the effects of abiotic predictors on species richness and composition individually, because they often appear together. The perception of ultimate drivers of bee assemblages composition should be appraised, since distinct bee groups have different diversity gradients patterns, as the relation of short-tongued bees with higher latitudes (Sakagami et al. 1967; Michener 1979; Roubik 1989), and the contrary pattern found in stingless bees (see below) and orchid bees (e.g., Moure 1967; Roubik and 
Table IV. Geographically weighted regression analysis (GWR). The dependent variables and models utilized here were the same models used in OLS.

\begin{tabular}{lccr}
\hline Dependent variable & $r^{2}$ & \multicolumn{1}{l}{$F$} \\
\hline SR & 0.448 & 3.98 & 0.001 \\
$\mathrm{H}^{\prime}$ & 0.392 & 3.339 & 0.003 \\
PIE & 0.289 & 2.414 & 0.018 \\
D & 0.153 & 1.538 & 0.102 \\
NMDS1 & 0.813 & 13.239 & $<0.001$ \\
NMDS2 & 0.538 & 4.22 & $<0.001$ \\
\hline
\end{tabular}

Hanson 2004), they both with higher species richness in forested areas at lower latitudes. Other important examples regard Centridini (see Silveira and Campos 1995; Zanella 2002) and some Tapinotaspidini bees (e.g., Arhysoceble, Caenonomada, Tapinotaspis, and Tapinotaspoides; Aguiar and Melo 2008), characteristic taxa in the Neotropical bee fauna that are much more related to open formations. Therefore, we cannot overlook the existence of a phylogenetic and biogeographic signal in the evolution of the communities of bees.

The positive response to the abiotic gradient is largely caused by the inherent evolutionary tendency of bees, but indirect response also must be taken in account to understand the role of abiotic variables. Temperature and precipitation gradients influences host plants communities in their richness, composition, and physiognomy, affecting differently bee species. Pollen and nectar are important resources for bees, but plants also provide resources for nesting, as leaves or cavities (Wcislo and Cane 1996). The availability of suitable substrates for nesting is one of the most important factors limiting the distribution of bee species (e.g., Michener 2007) and nesting biology is influenced by abiotic variables. Higher precipitation values, for instance, can be related to a severe restriction for soil nesting bees (Michener 1979) while, on the other side, in forested areas the availability of cavities may favor cavity-nesting species (e.g., Morato and Martins 2006).

Regarding the vegetation type, the richest assemblages found after rarefaction techniques 
were located in grasslands or in Mixed Ombrophilous Forests, a physiognomy strongly patched by grassland elements (Martins-Ramos et al. 2011). Grasslands seem to harbor the maximum plant species richness in small spatial grains (Wilson et al. 2012) what may have a significant impact on bee communities, especially taking into account the methodology used to study them (generally with low geographic coverage). Ecological theory foretold that habitats with higher resource availability (in this case, plant species) would allow higher species packing. But this statement does not seem to apply to social and solitary species in the same way. An important shift in community structure may benefit solitary species: towards the south, highly eusocial bees are generally less prominent in the bee assemblages (Roubik 1989; Camargo 1994; Biesmeijer and Slaa 2006). Biesmeijer and Slaa (2006) in particular observed that, regarding eusocial bee assemblages, the more food plant species the lower the species packing. According to them, an explanation for that might be that a wider range of food plants creates new niches for specialists, but does not necessarily create more niches for generalists, e.g., social bees. This statement was recently confirmed by Ebeling et al. (2011), who noted that flower resource specialization of solitary bees increased with increasing flowering plant species richness. Therefore, the increase on the number of available plant species, followed by the reduction in richness and abundance of "toughest competitors" (the highly eusocial bees) may benefit most bee groups.

A higher temporal species turnover may be a consequence of a direct influence of the temperature range on species richness and diversity. Temporal environmental variability can promote species richness (e.g., Chesson 2000; Soininen 2010) as species can exploit temporal niches created by environmental fluctuations (see White 2010). So, one should expect a higher rate of substitution of species along time, if temporal turnover is indeed larger in places with more pronounced temperature ranges. Besides, voltinism of tropical bees has been less studied than temperate zones bees (Cardoso and Silveira 2012), a general rule for insects is that the lower the latitude the greater is the number of generations produced per year (e.g., Ishihara 1998), since life history traits related to diapauses and voltinism are also a consequence of climatic adaptations (Tauber and Tauber 1981; Noriyuki et al. 2011). So, one could expect to find a significant number of univoltine species with a short lifespan in places with higher climatic variability. But of course this does not imply replacement of species along the year, as it may only reflect a strong seasonal pattern on bee assemblages. In spite of few studies on this issue, the seasonal pattern of activity appears to be a general characteristic of subtropical bee communities in Brazil (Kamke et al. 2011), where the richest assemblages are encountered.

We would like to emphasize that generalizations from our results should be viewed with caution for two main reasons. Firstly, our analyses did not consider data from Amazonian Forest and areas from higher latitudes (more than latitude -30 , mainly in Argentina). Surveying bees on forests are restrictive due to the difficulty of visualization and capture of bees (Silveira et al. 2002a), including the Atlantic Forest (e.g., Gonçalves and Brandão 2008), and the absence of data from the Amazonian bee fauna brings an enormous difficulty to evaluate the response of bees to broad ecological patterns, as the forest covers most portions of lower latitudes of South America. Assessments of bee assemblages from temperate areas south of -30 could also provide interesting results, helping to refine the perception of these patterns. In second place, available studies suggest that bee faunas are locally diverse in response to habitat heterogeneity (e.g., Gonçalves et al. 2009; Silveira and Campos 1995; Zanella 2003), highly variable in space and time, and often rich in rare species. All of these attributes indicate that intense sampling among sites and years will be required to characterize bee assemblages (Williams et al. 2001). But all is not lost. Besides a judicious choice of surveys for the dataset and the use of rarefaction techniques, bee communities as a whole seem to be stable in comparison to the stability of individual species (e.g., Wolda and Roubik 1996; Roubik and Ackerman 1987; Ebeling et al. 2011). And the power of subsamples 
to provide reliable estimates of bee richness, also dealing with different sampling efforts, cannot be disregarded (Cure et al. 1991; Williams et al. 2001).

We found that bee diversity and composition in eastern Neotropics respond to abiotic variables, according to the expected prediction that bees are positively related to latitude and, consequently, to its collinear components, a result, for sure, important to contextualize discussion on bee assemblages on the region. There is an intricate response of bees to a gradient of temperature, and assemblages along this gradient are understood to be important units of diversity, claiming for a wide preservation strategy. We see interesting perspectives with the future investigations based on structured inventories of communities from south and western portions of the continent, which will help expanding and refining our knowledge on the diversity of bees along the Neotropical Region.

\section{ACKNOWLEDGEMENTS}

We thank Antonio J. C. Aguiar and Gabriel A. R. Melo for early help on data tabulation and discussion. We are grateful to Eduardo A. B. Almeida for critically reading and reviewing the grammar and style of the manuscript, Rogério Rosa da Silva and Claus Rasmussen for critically reading the manuscript, Elaine D. G. Soares for helping with the preparation of Figures 1 and 6, and Peter Löwenberg Neto for providing the shape file of Neotropics depicted in Figure 1.

Corrélations entre facteurs abiotiques et diversité et composition des assemblages d'espèces d'abeilles le long de la zone néotropicale orientale

Apidae / Apoidea / diversité faunistique / pollinisateur

\section{Abiotische Faktoren korrelieren mit Diversität und Zusammensetzung von Bienenarten in der östlichen Neotropis}

Apidae / Apoidea / Bienenfauna / Diversiät / Bestäuber

\section{REFERENCES}

Abrahamczyk, S., Gottleuber, P., Matauschek, C., Kessler, M. (2011) Diversity and community composition of euglossine bee assemblages (Hymenoptera: Apidae) in western Amazonia. Biodivers. Conserv. 20, 29813001

Aguiar, A.J.C., Martins, C.F. (2003) The bee diversity of the Tabuleiro vegetation in the Guaribas Biological Reserve (Mamanguape, Paraíba, Brazil). In: Melo, G.A.R., Alves-dos-Santos, I. (eds.) Apoidea Neotropica: Homenagem aos 90 Anos de Jesus Santiago Moure, pp. 209-216. Editora UNESC, Criciúma

Aguiar, A.J.C., Melo, G.A.R. (2008) Biogeografia de áreas abertas da América do Sul, com ênfase em abelhas da tribo Tapinotaspidini (Hymenoptera, Apidae). In: de Jong, D., Francoy, T.M., Santana, W.C. (eds.) Anais do VIII Encontro sobre Abelhas, pp. 218-223. FUNPEC, Ribeirão Preto

Aguiar, C.M.L., Martins, C.F. (1997) Abundância relativa, diversidade e fenologia de abelhas (Hymenoptera, Apoidea) na caatinga, São João do Cariri, Paraíba. Brasil. Iheringia Ser. Zool. 83, 151-163

Aguiar, C.M.L., Zanella, F.C.V. (2005) Estrutura da comunidade de abelhas (Hymenoptera: Apoidea: Apiformis) de uma área na margem do domínio da caatinga (Itatim, BA). Neotrop. Entomol. 34, $15-24$

Albuquerque, P.M.C., Ferreira, R.G., Rêgo, M.M.C., Santos, C.S., Brito, C.M.S. (2001) Levantamento da fauna de abelhas silvestres (Hymenoptera: Apoidea) na região da "Baixada Maranhense": Vitória do Mearim, MA, Brasil. Acta Amaz. 31, 419-430

Almeida, M.C. (2003) Taxonomia e biocenótica de Apoidea (Hymenoptera) de áreas restritas de cerrado no município de Jaguariaíva, Paraná, sul do Brasil. $\mathrm{PhD}$ thesis, Universidade Federal do Paraná, Curitiba.

Barbola, I.F. (2000) Biocenótica de Apoidea (Hymenoptera) de uma área restrita da Floresta Atlântica, Morretes, Paraná, Brasil, e aspectos da ecologia da polinização de Stachytarpheta maximiliani (Verbenaceae). $\mathrm{PhD}$ thesis, Universidade Federal do Paraná, Curitiba.

Barbola, I.F., Laroca, S. (1993) A comunidade de Apoidea (Hymenoptera) da Reserva Passa Dois (Lapa, Paraná, Brasil): 1. Diversidade, abundância relativa e atividade sazonal. Acta Biol. Par. 22, 91-113

Biesmeijer, J.C., Slaa, E.J., de Castro, M.S., Viana, B.F., Kleinert, A.M.P., Imperatriz-Fonseca, V.L. (2005) Connectance of Brazilian social bee: food plant networks is influenced by habitat, but not by latitude, altitude or network size. Biota Neotrop. 5, 85-93

Biesmeijer, J.C., Roberts, S.P.M., Reemer, M., Oholemuller, R., Edwards, M., et al. (2006) Parallel declines in pollinators and insect-pollinated plants in Britain and the Netherlands. Science 313, 351-354

Biesmeijer, J.C., Slaa, E.J. (2006) The structure of eusocial bee assemblages in Brazil. Apidologie 37, 240-258

Boaventura, M.C. (1998) Sazonalidade e estrutura de uma comunidade de abelhas silvestres (Hymenoptera, Apoidea) numa área de cerrado do Jardim Botânico de Brasília, Distrito Federal. MSc thesis, Universidade de Brasília, Brasília. 
Bortoli, C., Laroca, S. (1997) Melissocenologia no Terceiro Planalto Paranaense. I: Abundância relativa das abelhas silvestres em um biótopo urbano de Guarapuava (PR, Brasil). Acta Biol. Par. 26, 51-86

Burnham, K.P., Anderson, D.R. (2002) Model selection and multimodel inference: a practical informationtheoretic approach. Springer, New York

Camargo, J.M.F. (1994) Biogeografia de Meliponini (Hymenoptera, Apidae, Apinae): a fauna Amazônica. In: Garófalo, C.A. (ed.) Anais do II Encontro sobre Abelhas, pp. 46-59. FFCLRP/USP, Ribeirão Preto

Cardoso, C.F., Silveira, F.A. (2012) Nesting biology of two species of Megachile (Moureapis) (Hymenoptera: Megachilidae) in a semideciduous forest reserve in southeastern Brazil. Apidologie 43, 71-81

Cassemiro, F.A.S., Barreto, B.S., Rangel, T.F.L.V.B., Diniz-Filho, J.A.F. (2007) Non-stationarity, diversity gradients and the metabolic theory of ecology. Global Ecol. Biogeogr. 16, 820-822

Chesson, P. (2000) Mechanisms of maintenance of species diversity. Annu. Rev. Ecol. Syst. 31, 343-366

Clarke, K.R., Warwick, R.M. (2001) Change in marine communities. An approach to statistical analysis and interpretation. Primer-E, Plymouth

Cure, J.R., Bastos, G.S.B., Oliveira, M.J.F., Souza, O.F. (1991) Influência do tamanho da amostra na estimativa da riqueza em espécies em levantamentos de abelhas silvestres (Hymenoptera, Apoidea). Rev. Bras. Zool. 7, 101-110

Diniz-Filho, J.A.F., Bini, L.M., Hawkins, B.A. (2003) Spatial autocorrelation and red herrings in geographical ecology. Global Ecol. Biogeogr. 12, 53-64

Ebeling, A., Klein, A.-M., Tscharntke, T. (2011) Plantflower visitor interaction webs: temporal stability and pollinator specialization increases along an experimental plant diversity gradient. Basic Appl. Ecol. 12, 300-309

Faria-Mucci, G.M., Camargo, J.M.F. (1996) A flora melitófila e a fauna de Apoidea em um ecossistema de campos rupestres, Serra do Cipó, Minas Gerais, Brasil. In: Garófalo, C.A. (ed.) Anais do II Encontro sobre Abelhas, pp. 217-224. FFCLRP/USP, Ribeirão Preto

Faria-Mucci, G.M., Melo, G.A.R., Campos, L.A.O. (2003) A fauna de abelhas (Hymenoptera, Apoidea) e plantas utilizadas como fonte de recursos florais, em um ecossistema de campos rupestres em Lavras Novas, Minas Gerais, Brasil. In: Melo, G.A.R., Alves-dosSantos, I. (eds.) Apoidea Neotropica: Homenagem aos 90 Anos de Jesus Santiago Moure, pp. 241-256. Editora UNESC, Criciúma

Gaston, K.J. (2000) Global patterns in biodiversity. Nature 405, 220-227

Gonçalves, R.B., Brandão, C.R.F. (2008) Diversidade de abelhas (Hymenoptera, Apidae) ao longo de um gradiente latitudinal na Mata Atlântica. Biota Neotrop. 8, 51-61

Gonçalves, R.B., Melo, G.A.R. (2005) A comunidade de abelhas (Hymenoptera, Apidae s.1.) em uma área restrita de campo natural no Parque Estadual de Vila Velha, Paraná: diversidade, fenologia e fontes florais de alimento. Rev. Bras. Entomol. 49, 557-571

Gonçalves, R.B., Melo, G.A.R., Aguiar, A.J.C. (2009) A assembléia de abelhas de uma area restrita de campos naturais do Parque Estadual de Vila Velha. Paraná e comparações com áreas de campos e cerrado. Pap. Avulsos Zool. 49, 163-181

Gotelli N.J., Entsminger G.L. (2004) EcoSim: Null models software for ecology. Version 7. Acquired Intelligence Inc. and Kesey-Bear. Burlington.

Grundel, R., Jean, R.P., Frohnapple, K.T., Glowacki, G.A., Scott, P.E., Pavlovic, N.B. (2010) Floral and nesting resources, habitat structure, and fire influence bee distribution across and open-forest gradient. Ecol. Appl. 20, 1678-1692

Hammer, O., Harper, D.A.T., Ryan, P.D. (2001) PAST: Paleontological statistics software package for education and data analysis. Palaeontol. Electron. 4, 1-9

Hijmans, R.J., Cameron, S.E., Parra, J.L., Jones, P.G., Jarvis, A. (2005) Very high resolution interpolated climate surfaces for global land areas. Int. J. Climatol. 25, 1965-1978

Hildebrand, H. (2004) On the generality of the latitudinal diversity gradient. Am. Nat. 163, 192-211

Hoffmann, M. (1990) Estrutura e importância de uma comunidade de abelhas no Rio Grande do Sul, para a polinização de plantas cultivadas. $\mathrm{PhD}$ thesis, Universidade Federal do Paraná, Curitiba.

Hurlbert, S.H. (1971) The non-concept of species diversity: a critique and alternative parameters. Ecology 52, 577-586

Ishihara, M. (1998) Geographic variation in insect developmental period: effect of host plant phenology on the life cycle of the bruchid seed feeder Kytorhinus sharpianus. Entomol. Exp. Appl. 87, 311-319

Jamhour, J., Laroca, S. (2004) Uma comunidade de abelhas silvestres (Hym., Apoidea) de Pato Branco (PRBrasil): diversidade, fenologia, recursos florais e aspectos biogeográficos. Acta Biol. Par. 33, 27-119

Jarque, C., Bera, A. (1980) Efficient tests for normality, homoscedasticity and serial independence of regression residuals. Econ. Let. 6, 255-259

Jetz, W., Rahbek, C., Lichstein, J.W. (2005) Local and global approaches to spatial data analysis in ecology. Global Ecol. Biogeogr. 14, 97-98

Kamke, R., Zillikens, A., Steiner, J. (2011) Species richness and seasonality of bees (Hymenoptera, Apoidea) in a restinga area in Santa Catarina, southern Brazil. Stud. Neotrop. Fauna Environ. 46, 35-48

Koellner, T., Hersperger, A.M., Wohlgemuth, T. (2004) Rarefaction method for assessing plant diversity on a regional scale. Ecography 27, 532-544

Kosior, A., Celary, W., Olejniczak, P., Fijal, J., Król, W., Solarz, W., Ponka, P. (2007) The decline of bumble bees and cuckoo bees (Hymenoptera: Apidae: Bombini) of western and central Europe. Oryx 41, 79-89 
Krug, C., Alves-dos-Santos, I. (2008) O uso de diferentes métodos para amostragem da fauna de abelhas (Hymenoptera: Apoidea), um estudo em Floresta Ombrófila Mista em Santa Catarina. Neotrop. Entomol. 37, 265-278

Laroca, S., Orth, I. (2002) Melissocoenology: historical perspective, methods of sampling, and recommendations. In: Kevan, P.G., Imperatriz-Fonseca, V.L. (eds.) Pollinating bees: the conservation link between agriculture and nature, pp. 217-225. Ministry of Environment, Brasília

Lazaridis, A. (2007) A note regarding the condition number: the case of spurious and latent multicollinearity. Qual. Quant. 41, 123-135

Ludwig, J.A., Reynolds, J.F. (1988) Statistical ecology: a primer on methods and computing. Wiley, New York

Madeira-da-Silva, M.C., Martins, C.F. (2003) Abelhas (Hymenoptera, Apoidea Apiformes) de uma área de restinga, Paraíba, Nordeste do Brasil: abundância, diversidade e sazonalidade. Rev. Nordest. Biol. 17, 75-90

Maia, C.M. (2008) Fauna de abelhas da Reserva Particular do Patrimônio Natural do Rio Cachoeira no município de Antonina, Paraná. MSc thesis, Universidade Federal do Paraná, Curitiba.

Martins, A.C., Melo, G.A.R. (2010) Has the bumblebee Bombus bellicosus gone extinct in the northern portion of its distribution range in Brazil? J. Insect Conserv. 14, 207-210

Martins, C.F. (1990) Estrutura da comunidade de abelhas (Hymenoptera, Apoidea) na Caatinga (Casa Nova, BA) e na Chapada Diamantina (Lençóis, BA). PhD thesis, Universidade de São Paulo, São Paulo.

Martins, C.F. (1994) Comunidade de abelhas (Hym., Apoidea) da caatinga e do cerrado com elementos de campo rupestre do estado da Bahia. Brasil. Rev. Nordest. Biol. 9, 225-257

Martins-Ramos, D., Chaves, C.L., Bortoluzzi, R.L.C., Mantovani, A. (2011) Florística de floresta ombrófila mista altomontana e de campos em Urupema, Santa Catarina. Brasil. Rev. Bras. Bioci. 9, 156-166

Mason, R.L., Gunst, R.F., Hess, J.L. (1989) Statistical design and analysis of experiments: applications to engineering and science. Wiley, New York

Mateus, S. (1998) Abundância relativa, fenologia e visita às flores pelos Apoidea do cerrado da estação Ecológica de Jataí-Luis Antonio-SP. MSc thesis, Faculdade de Filosofia, Ciências e Letras, Universidade de São Paulo, Ribeirão Preto.

Melo, G.A.R. (2007) Introductory Remarks. In: Moure, J.S., Urban, D. and Melo, G.A.R. (eds.) Catalogue of Bees (Hymenoptera, Apoidea) in the Neotropical Region, pp. v-xi. Sociedade Brasileira de Entomologia, Curitiba.

Michener, C.D. (1979) Biogeography of the bees. Ann. Mo. Bot. Gard. 66, 277-347

Michener, C.D. (2007) The bees of the world. The Johns Hopkins University Press, Baltimore
Millet-Pinheiro, P., Schlindwein, C. (2008) Comunidade de abelhas (Hymenoptera, Apoidea) e plantas em uma área do Agreste pernambucano. Brasil. Rev. Bras. Entomol. 52, 625-636

Minchin, P.R. (1987) An evaluation of relative robustness of techniques for ecological ordinations. Vegetatio 69, 89-107

Morato, E.F., Martins, R.P. (2006) An overview of proximate factors affecting the nesting behavior of solitary wasps and bees (Hymenoptera: Aculeata) in preexisting cavities in wood. Neotrop. Entomol. 35, 285-298

Morrone, J.J. (2006) Biogeographic ares ans transition zones of latin America and the caribbean islands based on panbiogeographic and cladistic analyses of the entomofauna. Annu. Rev. Entomol. 51, 467-494

Mouga, D.M.D.S., Krug, C. (2010) Comunidade de abelhas nativas (Apidae) em Floresta Ombrófila Densa Montana em Santa Catarina. Zoologia 27, 70-80

Moure, J.S. (1967) A check-list of the known euglossine bees (Hymenoptera: Apidae). Atas Simp. Biota Amaz. 5, 395-415

Neter, J., Wasserman, W., Kutner, M.H. (1989) Applied linear regression Models. McGraw-Hill, Homewood

Noriyuki, S., Akiyama, K., Nishida, T. (2011) Lifehistory tratits related to diapause in univoltine and bivoltine populations of Ypthima multistriata (Lepidoptera: Satyridae) inhabiting similar latitudes. Entomol. Sci. 14, 254-261

O'Brien, R.M. (2007) A caution regarding rules of thumb for variance inflation factors. Qual. Quant. 41, 673-690

Oliveira, F., Mendonça, M.W.A., Vidigal, M.C.S., Rego, M.M.C., Albuquerque, P.M.C. (2010) Comunidade de abelhas (Hymenoptera, Apoidea) em ecossistema de dunas na Praia de Panaquatira, São José de Ribamar, Maranhão. Brasil. Rev. Bras. Entomol. 54, 82-90

Pedro, S.R.M. (1992) Sobre as abelhas (Hymenoptera, Apoidea) em um ecossistema de cerrado (Cajuru, Estado de São Paulo): composição, fenologia e visita às flores. MSc thesis, Faculdade de Filosofia, Ciências e Letras, Universidade de São Paulo, Ribeirão Preto.

Pinheiro-Machado, C. (2002) Brazilian bee biodiversity: what has been done and what is to be done. In: Garófalo, C.A., Freitas, G. (eds.) Anais do V Encontro Sobre Abelhas, pp. 95-107. FUNPEC, Ribeirão Preto

Ramalho, M. (1995) A diversidade de abelhas (Apoidea, Hymenoptera) em um remanescente de Floresta Atlântica, em São Paulo. PhD thesis, Universidade de São Paulo, São Paulo.

Rangel, T.F., Diniz-Filho, J.A.F., Bini, L.M. (2010) SAM: a comprehensive application for spatial analysis in macroecology. Ecography 33, 46-50

Roubik, D.W. (1989) Ecology and natural history of tropical bees. Cambridge University Press, New York

Roubik, D.W., Ackerman, J.D. (1987) Long-term ecology of euglossine orchid-bees (Apidae: Euglossini) in Panama. Oecologia 73, 321-333 
Roubik, D.W., Hanson, P.E. (2004) Orchid bees of tropical America: biology and field guide. INBIO, San Jose

Sakagami, S.F., Laroca, S., Moure, J.S. (1967) Wild bee biocoenotics in São José do Pinhais (PR), South Brazil. Preliminary report. J. Fac. Sci. Hokkaido Univ. Ser 6 (Zool.) 16, 253-291.

Sanders, H.L. (1968) Marine benthic diversity: a comparative study. Am. Nat. 102, 243-282

Santiago, L.R., Brito, R.M., Muniz, T.M.V.L., Oliveira, F.F., Francisco, F.O. (2009) A fauna apícola do Parque Municipal Cachoeirinha (Iporá, GO). Biota Neotrop. 9, 393-397

Santos, M.F., Carvalho, C.A.L., Silva, R.F. (2004) Diversidade de abelhas (Hymenoptera: Apoidea) em uma área de transição Cerrado-Amazônia. Acta Amaz. 34, 319-328

Schleuning, M., Farwig, N., Peters, M.K., Bergsdorf, T., Bleher, B., et al. (2011) Forest fragmentation and selective logging have inconsistent effects on multiple animal-mediated ecosystem processes in a tropical forest. PLoS ONE. doi:10.1371/journal.pone.0027785

Silveira, F.A., Campos, M.J.O. (1995) A melissofauna de Corumbataí (SP) e Paraopeba (MG) e uma análise da biogeografia das abelhas do cerrado brasileiro (Hymenoptera, Apoidea). Rev. Bras. Entomol. 39, $371-401$

Silveira, F.A., Melo, G.A.R., Almeida, E.A.B. (2002a) Abelhas brasileiras: sistemática e identificação. Author's edition, Belo Horizonte

Silveira, F.A., Pinheiro-Machado, C., Alves-dos-Santos, I., Imperatriz-Fonseca, V.L., Kleinert, A.M.P. (2002b) Taxonomic constraint for the conservation and sustainable use of wild pollinators - the Brazilian wild bees. In: Kevan, P.G., Imperatriz-Fonseca, V.L. (eds.) Pollinating bees: the conservation link between agriculture and nature, pp. 41-50. Ministry of Environment, Brasília

Simberloff, D.S. (1972) Properties of the rarefaction diversity measurement. Am. Nat. 106, 414-418

Soininen, J. (2010) Species turnover along abiotic and biotic gradients: patterns in space equal patterns in time? BioScience 60, 433-439

Steffan-Dewenter, I. (2003) Importance of habitat area and landscape context for species richness of bees and wasps in fragmented orchard meadows. Conserv. Biol. 17, 1036-1044

Sydney, N.V., Gonçalves, R.B., Faria, L.R.R. (2010) Padrões espaciais na distribuição de abelhas Euglossina (Hymenoptera, Apidae) da região Neotropical. Pap. Avulsos Zool. 50, 667-679

Tauber, C.A., Tauber, M.J. (1981) Insect seasonal cycles: genetics and evolution. Annu. Rev. Ecol. Syst. 12, 281-308

Thadewald, T., Büning, H. (2007) Jarque-Bera test and its competitors for testing normality - a power comparison. J. Appl. Stat. 34, 87-105
Warton, D.I., Hui, F.K.C. (2011) The arcsin is asinine: the analysis of proportions in ecology. Ecology 92, 3-10

Wcislo, W.T., Cane, J.H. (1996) Floral resource utilization by solitary bees (Hymenoptera: Apoidea) and exploitation of their stored food by natural enemies. Annu. Rev. Entomol. 41, 257-286

Weiss, G. (2008) A fauna de abelhas (Hymenoptera, Apidae) do Parque Estadual de Campinhos, Paraná, Brasil. Undergraduate thesis, Universidade Federal do Paraná, Curitiba.

Wilms, W. (1995) Die bienenfauna im Küstenregenwald Brasiliens und ihre Beziehungen zu Blütenplanzen: Fallstudie Boracéia, São Paulo. PhD thesis, Fakultät für Biologie der Eberhard-Karls-Universität Tübingen, Tübingen.

Williams, N.M., Minckley, R.L., Silveira, F.A. (2001) Variation in native bee faunas and its implications for detecting community changes. Conserv. Ecol. 5. Available in: http://www.consecol.org/vol5/iss1/ $\operatorname{art} 7 /$.

Willig, M.R., Kaufman, D.M., Stevens, R.D. (2003) Latitudinal gradients of biodiversity: pattern, process, scale and synthesis. Annu. Rev. Ecol. Evol. Syst. 34, 273-309

Wilson, J.B., Peet, R.K., Dengler, J., Pärtel, M. (2012) Plant species richness: the world records. J. Veg. Sci. 23, 796-802

White, E.P., Morgan Ernest, S.K., Adler, P.B., Hurlbert, A.H., Kathleen Lyons, S. (2010) Integrating spatial and temporal approaches to understanding species richness. Philos. Trans. R. Soc. B 365, 3633-3643

Wolda, H., Roubik, D.W. (1996) Nocturnal bee abundance and seasonal bee activity in a Panamanian forest. Ecology 67, 426-433

Winfree, R., Aguilar, R., Vazquez, D.P., LeBuhn, G., Aizen, M.A. (2009) A meta-analysis of bees responses to anthropogenic disturbance. Ecology 90, 2068-2076

Zanella, F.C.V. (2000) The bees of the Caatinga (Hymenoptera, Apoidea, Apiformes): a species list and comparative notes regarding their distribution. Apidologie 31, 579-592

Zanella, F.C.V. (2002) Sistemática, filogenia e distribuição geográfica das espécies sul-americanas de Centris (Paracentris) Cameron, 1903 e de Centris (Penthemisia) Moure, 1950, incluindo uma análise filogenética do "grupo Centris" sensu Ayala 1998 (Hymenoptera, Apoidea, Centridini). Rev. Bras. Entomol. 46, 435-488

Zanella, F.C.V. (2003) Abelhas da Estação Ecológica do Seridó (Serra Negra do Norte, RN): aportes ao conhecimento da diversidade, abundância e distribuição espacial das espécies na Caatinga. In: Melo, G.A.R., Alves-dos-Santos, I. (eds.) Apoidea Neotropica: Homenagem aos 90 Anos de Jesus Santiago Moure, pp. 231-240. Editora UNESC, Criciúma 